\title{
Effect of land-use types on the ecomorphological structure of fish assemblage in distinct mesohabitats of neotropical streams
}

\author{
Leonardo Antunes Pessoa ${ }^{1 *\left({ }^{(}\right)}$, Matheus Tenório Baumgartner ${ }^{1}$, Marcelo Percilio Santana Junior ${ }^{1}$, João \\ Paulo Alves Pagotto ${ }^{2}$, Luiz Gustavo Antunes Pessoa ${ }^{3}$ \& Erivelto Goulart ${ }^{1,4}$ \\ ${ }^{1}$ Universidade Estadual de Maringá, Programa de Pós-graduação em Ecologia de Ambientes Aquáticos \\ Continentais, Av. Colombo, 87020-900, Maringá, PR, Brasil. \\ ${ }^{2}$ Universidade Estadual do Paraná, Departamento de Ciências Biológicas, Av. Gabriel Esperidião, 87703-000, \\ Paranavaí, PR, Brasil. \\ ${ }^{3}$ Universidade Estadual de Maringá, Programa de Pós-graduação em Biotecnologia Ambiental, Av. Colombo, \\ 87020-900, Maringá, PR, Brasil \\ ${ }^{4}$ Universidade Estadual de Maringá, Núcleo de Pesquisas em Limnologia, Ictiologia e Aquicultura, Av. \\ Colombo, 87020-900, Maringá, PR, Brasil. \\ *Corresponding author: leonardo_antunes15@hotmail.com
}

PESSOA, L.A., BAUMGARTNER, M.T., SANTANAJUNIOR, M.P., PAGOTTO, J.P.A., PESSOA, L.G.A., GOULART, E. Effect of land-use types on the ecomorphological structure of fish assemblage in distinct mesohabitats of neotropical streams. Biota Neotropica 21(3): e20201034. https://doi.org/10.1590/1676-0611-BN-2020-1034

\begin{abstract}
The use and occupation of land by human population substantially influence environmental variables and fish assemblage in streams. However, there is little knowledge on how these changes affect the ecomorphological structure of fish assemblage in mesohabitats. Therefore, we aim to assess whether the land-use types affect the ecomorphological structure of fish assemblage in distinct mesohabitats. Environmental and ichthyofaunistic data were collected in three mesohabitats (rifles, runs, and pools) of five rural and five urban streams. Twenty-one ecomorphological indices were obtained from the mean of linear morphological measurements and areas of the fishes. Subsequently, the Euclidean distance was calculated, based on the ecomorphological indices, between each pair of species, to measure the ecomorphological distances for the mesohabitats of the rural and urban streams. The results show that the urban environment is more harmful to streams than the rural one, due to changes in the environmental variables and decrease in species richness. The main environmental changes found in urban streams were the decrease in canopy cover by riparian vegetation and dissolved oxygen, and the increase in electrical conductivity and bed silting. Also, there was a significant decrease in the morphological similarity between fish species in the mesohabitats of urban streams compared to rural ones. Therefore, we can conclude that the urban environment leads to the loss of morphologically similar fish species in the mesohabitats, with only a few functionally distinct species remaining.
\end{abstract}

Keywords: urban ecosystem; headwater streams; ecomorphological distances; fauna homogenization.

\section{Efeito dos tipos de uso do solo na estrutura ecomorfológica da assembleia de peixes em distintos mesohábitats de riachos neotropicais}

Resumo: O uso e ocupação do solo pela população humana influencia substancialmente as variáveis ambientais e a assembleia de peixes em riachos. No entanto, há pouco conhecimento de como estas alterações afeta a estrutura ecomorfológica da assembleia de peixes em mesohábitats. Portanto, objetiva-se avaliar se o tipo do uso do solo afeta a estrutura ecomorfológica da assembleia de peixes nos distintos mesohábitats. Dados ambientais e ictiofaunísticos foram coletados em três mesohabitats (corredeiras, rápidos e remansos) de cinco riachos rurais e cinco urbanos. Vinte e um índices ecomorfológicos foram obtidos a partir das médias das medidas morfológicas lineares e áreas dos peixes. Posteriormente, a distância Euclidiana foi calculada, baseada nos índices ecomorfológicos, entre cada par de espécies, afim de mensurar as distâncias ecomorfológicas para os mesohábitats dos riachos rurais e urbanos. Os resultados mostram que o ambiente urbano é mais danoso aos riachos do que o rural, devido a diminuição da riqueza de espécies e as alterações nas variáveis ambientais. As principais mudanças ambientais encontradas em riachos urbanos foram a diminuição da cobertura do dossel pela vegetação ripária e do oxigênio dissolvido e o aumento da condutividade elétrica e do assoreamento do leito. Além disso, houve uma diminuição significativa da similaridade morfológica entre as espécies de peixes nos mesohábitats de riachos urbanos em comparação com os rurais. Portanto, podemos concluir que o ambiente urbano leva à perda de espécies de peixes morfologicamente similares nos mesohábitats, restando apenas algumas espécies funcionalmente distintas. Palavras-chave: ecossistema urbano; riachos de cabeceira; distâncias ecomorfológicas; homogeneização da fauna. 


\section{Introduction}

The alteration of natural landscapes caused by anthropogenic activities is one of the greatest threats to biodiversity worldwide (Sala et al. 2000, Foley et al. 2005). The use and occupation of land by the human population, such as rural and urban landscapes, are responsible for influencing several environmental factors of streams, such as hydrology, channel morphology, and water quality and toxicity (Allan 2004, Walsh et al. 2005, Cunico et al. 2012). Although both rural and urban landscapes cause environmental damage to streams (Tóth et al. 2019), comparative studies have shown that the urban environment is generally more harmful to stream fish assemblages than the rural one (Cunico et al. 2006, 2012, Alexandre et al. 2010, Cruz \& Pompeu, 2020). This difference in the preservation condition of the streams have been associated with the presence of an impermeable surface in the drainage basin (Wang et al. 2001, Cunico et al. 2012), which increases the strength of the runoff, causing more drastic changes in the hydrological and geomorphological variables of these ecosystems, such as increased flow velocity, erosion of the margin, and sedimentation of the channel (Wood \& Armitage 1997, Hancock 2002, Booth et al. 2004, Hasenmueller et al. 2017). A common response of the fish assemblage to urbanization is the decrease in the diversity of native species and the dominance by few exotic ones (Walters et al. 2003, Perkin et al. 2019). However, the effects of the land use on fish assemblages are still largely evaluated only by metrics that consider the number of species (species richness) and their abundance (Weaver \& Garman 1994, Wang et al. 2001, Walsh et al. 2005, Cunico et al. 2006, 2012, Tóth et al. 2019). Such metrics, based on taxonomic identity, provides an incomplete response to changes in biodiversity, as they assume that all species contribute equally to the functioning of the ecosystem and sometimes fail to detect changes caused by anthropogenic activities (Rabeni \& Smale 1995, Villéger et al. 2010, Teresa \& Casatti 2012, Casatti et al. 2015). Therefore, it is necessary to use the functional characteristics of the species as a complementary approach to assess the impact of land use on the fish assemblage, instead of only taxonomic identity (Brown et al. 2009, Cunico et al. 2011, Kern \& Langerhans 2018).

Morphological traits have been widely used to qualify the functions that species develop in a given ecosystem (Moreno et al. 2006, Villéger et al. 2010, Inward et al. 2011, Toussaint et al. 2016), with a premise that adaptive changes in the phenotype are capable of producing differences in species performance, which consequently generates changes in the use of resources (Wikramanayake 1990, Casatti \& Castro 2006, Oliveira et al. 2010, Pagotto et al. 2011). The interaction between morphology and ecological aspects of species is the basis of ecomorphology (PeresNeto 1999) and provides support for the use of morphology as a tool to determine the functional characteristics of species (Pease et al. 2012). In this approach, the ordering of morphological traits in multivariate analysis is used to evaluate the diversification of niches and ecological functions existing in a given ecosystem (Winemiller 1991, Villéger et al. 2010). Consequently, from the calculation of interspecific ecomorphological distances, it becomes possible to estimate the niche space occupied by the assemblages and describe the pattern of functional similarity existing among its members ( Winemiller 1991; Montaña et al. 2014).

Streams are considered complex ecosystems, and their communities are influenced by several factors operating at multiple scales (Cunico et al. 2012, Barbosa et al. 2019). On a local scale, streams can be understood as a mosaic of mesohabitats (rifles, runs, and pools) that are delimited by different combinations of current velocity, depth, and substrate composition (Rincón 1999). Riffles are characterized as areas of high gradient, with fast and turbulent waters and rocky substrate; runs also have relatively fast waters, but are generally deeper than riffles, with a smaller gradient and non-turbulent waters; pools are deep areas with low current velocity, and the presence of fine substrate is common. These hydrological and geomorphological differences among the mesohabitats act as environmental filters for the fish assemblage, selecting the species mainly by the body shape (Wikramanayake 1990, Leal et al. 2011, Kano et al. 2013). For example, the high current velocity of the riffles favors species with a dorsoventrally depressed body, while the low velocity of the pools is associated to species with a laterally compressed body (Gaston et al. 2012). Therefore, we can expect that the fish assemblage in the mesohabitats would show high morphological similarity between species. However, there is little knowledge on how changes in the environmental variables of streams caused by land-use types (e.g. rural and urban environment) affect the ecomorphological structure of fish assemblage in the mesohabitats.

Previous studies have shown that environmental changes in streams caused by land use affect the availability of micro and mesohabitats (Zeni et al. 2019), influencing the distribution of fish species along the channel (Berkman \& Rabeni 1987, Teresa \& Casatti 2012). For example, the silting of streams usually buries the coarse substrate (Walters et al., 2003), leading to a decrease of species that inhabit the riffles (i.e. species with a dorsoventrally depressed body) and can create microhabitats for species adapted to pools (i.e. species with a laterally compressed body) (Berkman \& Rabeni 1987). This reorganization of the assemblage along the stream results in the homogenization of species composition among mesohabitats (Berkman \& Rabeni 1987, Teresa $\&$ Casatti 2012). Therefore, it is expected that this homogenization of species would decrease the morphological similarity between species and increase the volume of ecomorphological space in mesohabitats.

In this context, we conducted the study in three mesohabitats (riffles, runs, and pools) of streams inserted in the rural and urban environment to assess whether the land-use type influences the ecomorphological structure of the fish assemblage in the mesohabitats. We hypothesized that (i) urban streams would have less preserved environmental conditions and less species richness compared to rural ones, (ii) mesohabitats of urban streams would present fish assemblage with less morphological similarity between species, and (iii) greater volume of ecomorphological space than rural mesohabitats.

\section{Materials and methods}

\section{Study Area}

This study was carried out in ten low-order streams (1st to 3rd order) belonging to the Pirapó River Basin, close to and inserted in the metropolitan region of Maringá, southern Brazil. The Pirapó River Basin is located in the northern region of the state of Paraná, specifically in the polygon bounded by latitudes of $22^{\circ} 30$ ' and $23^{\circ} 30^{\prime}$ S and longitudes of $51^{\circ} 15^{\prime}$ and $52^{\circ} 15^{\prime} \mathrm{W}$ (Figure 1). With a drainage area of approximately $5,000 \mathrm{~km}^{2}$ and an extension of $168 \mathrm{~km}$, the Pirapó River is one of the main tributaries of the Paranapanema River, in the upper Paraná River Basin (Maak 2002). The climate of the region is subtropical, being classified, according to Köppen, as a hot humid climatic zone, Cfa (h) 


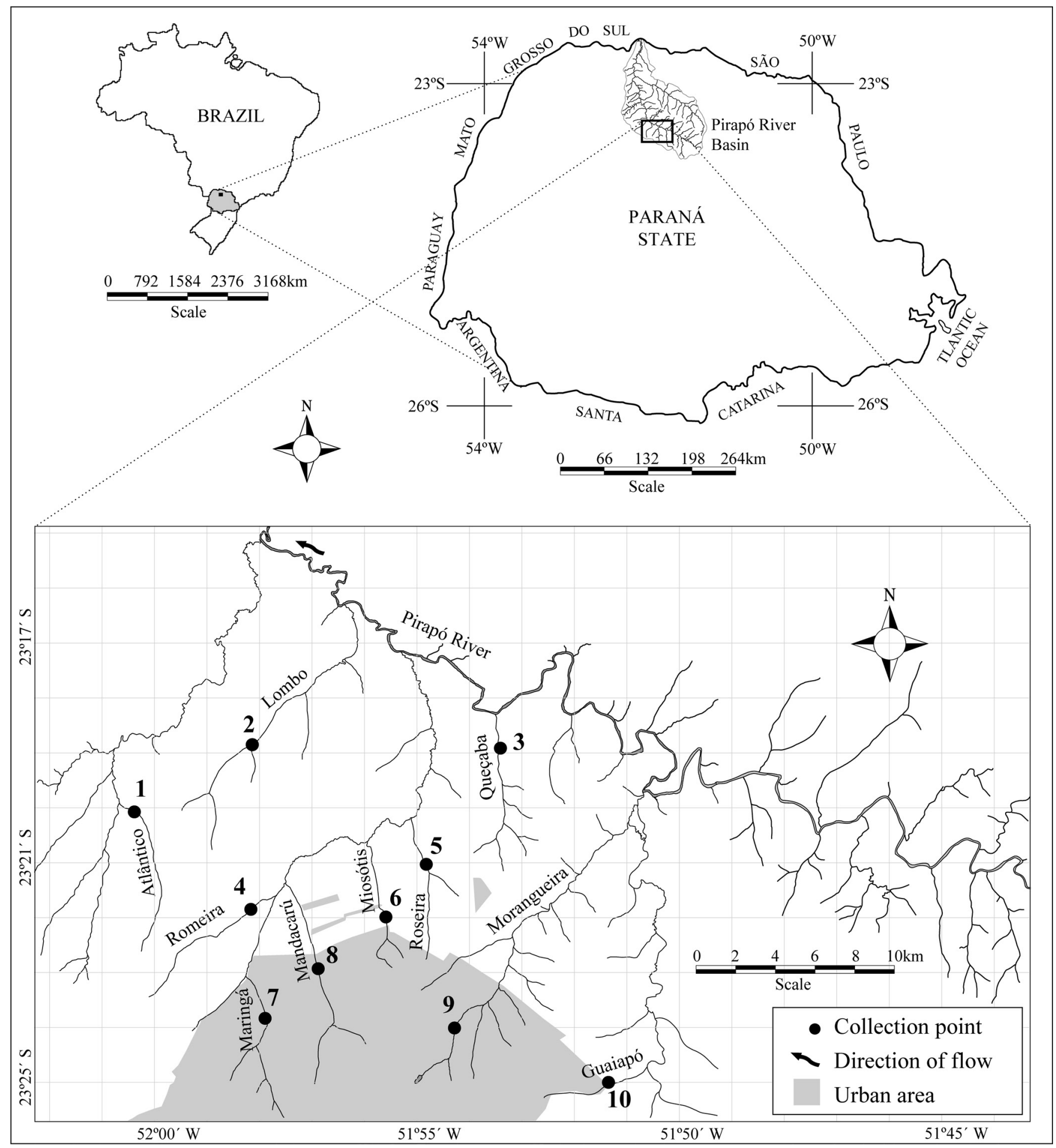

Figure 1. Location of collection points in rural (1-5) and urban (6-10) streams in the Pirapó River Basin, Maringá, Brazil.

(Maack 2002). The annual rainfall levels exceed $1,000 \mathrm{~mm}$, while the average annual temperatures vary between 16 and $20^{\circ} \mathrm{C}$, with January being the hottest and most humid month and July the coldest and driest (Passos 2007).

\section{Data sampling}

Data sampling was carried out in April and May 2017, in three mesohabitats (riffles, runs, and pools) of ten streams, five inserted in the rural environment, and five in the urban one (Figure 1), totaling 30 collection points. Before the collection day, we visited several stretches along the streams and selected the one that had the three mesohabitats next to each other, to facilitate data collection. Thus, mesohabitats were visually selected in sequence or very close to each other, according to the characterization presented by Rincón (1999): riffles had fast and turbulent waters, with a substrate composed of large, worn, and round rocks; runs had relatively fast-running waters but were deeper than 
riffles, with less turbulent waters; pools were deep areas where the current was slow, which allowed for fine sediment in the substrate. The longitudinal extension of each mesohabitat was standardized in ten meters in length, where the following environmental variables were measured: depth $(\mathrm{cm})$ and width $(\mathrm{m})$ of the channel, proportion of flooded vegetation (\%), canopy cover by riparian vegetation (\%) and substrate type (clay, sand, rock, or civil construction waste; $\%)$, current velocity $(\mathrm{m} / \mathrm{s}$; with a JDC electronic flowmeter, model Flowatch FL-K2), $\mathrm{pH}$ (DIGIMED, model DM-22), dissolved oxygen $(\mathrm{mg} / \mathrm{L}$; DIGIMED, model DM-4P) and electrical conductivity $(\mu \mathrm{S} / \mathrm{cm}$; DIGIMED, model DM-32).

The width of the channel was measured upstream, downstream and in the center of each mesohabitat, while the other variables were taken at nine points, also comprising the left and right margins, and an intermediate point. The quantification of the area of flooded vegetation, canopy cover, and type of substrate was done with a $0.25 \mathrm{~m}^{2}$ wooden square, subdivided into 25 smaller squares of $0,01 \mathrm{~m}^{2}$, with their values being estimated from the sum of the filled subdivisions. After quantifying the variables, their averages were calculated to characterize the mesohabitats according to their environmental conditions.

The fish collection was done using electrofishing (portable generator of alternating current, $2,500 \mathrm{~W}, 400 \mathrm{~V}, 2 \mathrm{~A}$ ), through three consecutive passes of the puçás in each mesohabitat. As mesohabitats were selected in sequence or very close to each other, before any procedure, they were blocked by multifilament nets with $2 \mathrm{~mm}$ between opposite nodes. The captured specimens were anesthetized with benzocaine and sacrificed. After death, they were fixed in a $4 \%$ formaldehyde solution and, after taking their morphological measures, transferred to $70^{\circ} \mathrm{GL}$ alcohol. The collected fish were identified according to Ota et al. (2018), and the exemplary testimonies were deposited in the Ichthyological Collection of the Nupélia/UEM (lots: NUP 20040 to NUP 20128). The collects were made under the license of the Instituto Chico Mendes de Conservação da Biodiversidade (ICMBIO) $n^{\circ}$. 25560-1.

\section{Ecomorphological data}

Linear morphometric measurements and areas related to the fish's trunk, fins, head, eyes, and mouth were taken from ten individuals, when possible, of each species using a digital caliper $(0.01 \mathrm{~mm}$ approximation). The eyes were photographed and the fins were drawn on sheets of sulfite paper, after which their areas were calculated in the program ImageJ (Rasband 2012), through digitized drawings and photographs. Only adult individuals were used since ontogenetic growth can promote changes in morphology (Russo et al. 2007), feeding habits (Novakowski et al. 2004), and habitat use (Gratwicke et al. 2006). The following morphological traits were measured: standard length, maximum body height, body midline height, maximum body width, caudal peduncle length, caudal peduncle height, caudal peduncle width, head length, head height, head width, eye height, mouth height, mouth width, caudal fin height, anal fin length, pectoral fin length, pelvic fin length, eye area, dorsal fin area, anal fin area, caudal fin area, pectoral fin area, and pelvic fin area.

Species with only one individual collected in a given mesohabitat were disregarded from the ecomorphological analysis for that mesohabitat, but considered for the others where they presented more than one individual. This procedure was taken to minimize the influence of species in which few individuals only transit between mesohabitats, but do not have morphological adaptations for that mesohabitat. In this way, even though mesohabitats are blocked with waiting nets, there is the possibility of capturing individuals who passed through before the blockade. Therefore, the following species were disregarded, from a given mesohabitat, from ecomorphological analysis: riffles in a rural environment - Psalidodon aff. fasciatus, Astyanax lacustris, Imparfinis borodini, Poecilia reticulata, Rineloricaria aff. latirostris; runs in a rural environment - Geophagus brasiliensis, Hisonotus francirochai, Hypostomus cf. nigromaculatus, Rineloricaria aff. latirostris; runs in an urban environment - Piabina argentea; pools in a rural environment - Bryconamericus stramineus, Characidium aff. zebra, Hoplias aff. malabaricus, Hypostomus hermanni, Oligosarcus paranensis, Pimelodella avanhandavae; pools in an urban environment - Piabina argentea. Gymnotus inaequilabiatus was also excluded from ecomorphological analysis, due to the absence of even fins which made it impossible to compare them with others concerning their measurements.

From the mean of linear morphometric measurements and area for each species, ecomorphological indices were calculated (Table 1). This procedure allows the evaluation of information restricted to differences between forms and promotes independence of the analysis regarding the size of the specimens. Although body size is recognized as an important factor in ecological relationships between fish (Layman et al. 2005), significant differences in body dimensions can lead to a trend in data variation related exclusively to the size of the specimens. Thus, the use of indices reduces the chances of the analyzes being dominated by a single variable (Winemiller 1991). Some authors made use of indices in their studies, assuming that, by expressing the shape of the morphological structures, the indices may reveal their ecological roles (Winemiller 1991, Willis et al. 2005, Casatti \& Castro 2006, Montaña \& Winemiller 2010, Montaña et al. 2014, Oliveira et al. 2010, Pagotto et al. 2011). In this study, 21 ecomorphological indices were used to represent the occupation of the trophic and spatial niche by species (Table 1).

\section{Data Analysis}

To characterize mesohabitats according to their environmental conditions, all variables were transformed to zero mean and unit variance and then summarized by Principal Component Analysis (PCA). The broken-stick model was used as a criterion for assessing the significance of the axes. The Analysis of Variance (two-way ANOVA) was applied to evaluate whether there was a separation of the points according to the factors land-use types (rural and urban) and mesohabitats (rifles, runs, and pools) in the first two axes of the PCA.

We applied a mantel correlogram to analyze whether the fish assemblage composition is associated with the spatial distance between the collection points. The first matrix was generated through the Jaccard distance calculated on the presence/absence of the species. The second matrix was obtained from the calculation of the distance, in kilometers, between the collection points in the QGIS program (QGIS Development Team 2018), using the stream network of the Pirapó River basin, downloaded from the website of the Instituto Água e terra do Paraná (IAT 2021), and the geographical coordinates of the collection points.

A second PCA was performed on the correlation matrix of ecomorphological indices, to characterize the tendency for interspecific variation in the multivariate ecomorphological space between fish assemblages. As in the first PCA, the broken-stick model was used, in which the axes with eigenvalues greater than those generated by the 
Table 1. Linear morphometric variables and areas used in the calculation of ecomorphological indices and their respective ecological meanings. The following morphological characters were used: Standard Length (SL), Maximum Body Height (MBH), Midline Height (MH), Maximum Body Width (MBW), Caudal Peduncle Length (CPL), Caudal Peduncle Height (CPH), Caudal Peduncle Width (CPW), Head Length (HL), Head Height (HH), Head Width (HW), Eye Height (EH), Mouth Height (MoH), Mouth Width (MoW), Caudal Fin Height (CFH), Anal Fin Length (AFL), Pectoral Fin Length (PcFL), Pelvic Fin Length (PvFL), Eye Area (EA), Caudal Fin Area (CFA), Anal Fin Area (AFA), Pectoral Fin Area (PcFA), Pelvic Fin area (PvFA), Dorsal Fin area (DFA).

\begin{tabular}{|c|c|c|}
\hline Indices & Formula & Meaning \\
\hline 1. Compression index & $\mathrm{MBH} / \mathrm{MBW}$ & $\begin{array}{l}\text { High values indicate fish with a laterally compressed body, which is expected fo } \\
\text { species that occupy habitats with low current velocity (Gatz Jr. 1979, Watson \& Ba } \\
\text { 1984). }\end{array}$ \\
\hline 2. Depression index & $\mathrm{MH} / \mathrm{MBH}$ & $\begin{array}{l}\text { Low values indicate fish with a dorsoventrally depressed body, which is expected } \\
\text { species that explore habitats with high current velocity, as this body shape helps t } \\
\text { fish to stay in the water column without having to swim (Watson \& Balon 1984) }\end{array}$ \\
\hline $\begin{array}{l}\text { 3. Relative length of caudal } \\
\text { peduncle }\end{array}$ & $\mathrm{CPL} / \mathrm{SL}$ & $\begin{array}{l}\text { Fish with a long caudal peduncle are good swimmers. However, fish adapted to high } \\
\text { current velocity, but not necessarily nektonic species, such as the Siluriformes, also hav } \\
\text { long caudal peduncles (Watson \& Balon 1984). }\end{array}$ \\
\hline $\begin{array}{l}\text { 4. Relative height of caudal } \\
\text { peduncle }\end{array}$ & $\mathrm{CPH} / \mathrm{MBH}$ & Low values indicate high maneuverability (Winemiller 1991, Willis et al. 2005). \\
\hline $\begin{array}{l}\text { 5. Relative width of caudal } \\
\text { peduncle }\end{array}$ & $\mathrm{CPH} / \mathrm{MBW}$ & High values indicate continuous swimmers (Winemiller 1991, Willis et al. 2005). \\
\hline
\end{tabular}

6. Relative length of head

7. Relative height of head

8. Relative width of head

9. Relative height of mouth

10. Relative widht of mouth

11. Vertical eye position

12. Relative area of eye

$\mathrm{EA} /(\mathrm{SL})^{2}$

13. Relative area of dorsal fin DFA/(SL) $)^{2}$

14. Relative area of caudal fin $\mathrm{CFA} /(\mathrm{SL})^{2}$

15. Aspect ratio of caudal fin

16. Relative area of anal fin

17. Aspect ratio of anal fin

18. Relative area of pectoral fin

19. Aspect ratio of pectoral fin

$(\mathrm{PcFL})^{2} / \mathrm{PcFA}$

20. Relative area of pelvic fin

$\mathrm{PvFA} /(\mathrm{SL})^{2}$

21. Aspect ratio of pelvic fin

$\mathrm{AFA} /(\mathrm{SA})^{2}$

$(\mathrm{AFL})^{2} / \mathrm{AFA}$

$\operatorname{PcFA} /(\mathrm{SL})^{2}$
$(\mathrm{CFH})^{2} / \mathrm{CFA}$
$(\mathrm{PvFL})^{2} / \mathrm{PvFA}$
High values of these indices are found in fish that feed on larger prey, therefore, higher rates are expected for piscivorous species (Watson \& Balon 1984, Winemiller 1991, Pouilly et al. 2003, Willis et al. 2005).

The relative height of the mouth allows inferring about the relative size of the prey (Gatz Jr. 1979).

Index related to the size of the mouth, suggesting relatively large prey for indexes with high values (Gatz Jr. 1979, Winemiller 1991).

This index is associated with the species' foraging position in the water column. High values indicate benthic fish (eyes located dorsally), while low values indicate nektonic fish (side eyes) (Gatz Jr. 1979).

This index is related to food detection and provides information on the visual acuity of the species (Pouilly et al. 2003). It can indicate the position of the species in the water column, as species that inhabit deeper areas have smaller eyes (Gatz Jr. 1979, Piet, 1998, Wikramanayake, 1990).

Larger relative areas have greater yaw stabilization capacity (Breda 2005). Large areas are important for acceleration (Oliveira et al. 2010).

Fish with a high aspect ratio of caudal fins are more active and continuous swimmers, in which there is a tendency for a forked caudal fin and reduced area (Keast \& Webb 1966, Gatz Jr. 1979)

Larger relative areas imply greater maneuverability and movement stabilization (Breda 2005).

Larger aspect ratios imply a greater ability to perform faster progressive and retrograde movements (Breda 2005).

Relatively larger areas of the pectoral fin are found in slow-swimming species, which use it for maneuverability (some characids) and may also be high among fish that inhabit high-current regions such as the Siluriformes. Smaller areas are found in pelagic fish (Watson \& Balon 1984).

A high ratio indicates long, narrow pectoral fin, which is expected in fish that swim continuously and reach high speed, and consequently prefer pelagic regions (Oliveira et al. 2010).

Relatively larger areas of the pelvic fin are found in benthic fish and smaller areas in pelagic fish (Breda 2005).

The highest values are found in pelagic fish and are related to the ability to balance. The lower values are associated with fish that prefer rocky habitats to support the body to the substrate (Gatz Jr. 1979). 
model were used in ecomorphological analysis. From the PCA, the Euclidean Distance was calculated between the scores of each pair of species, on the axes that presented eigenvalues greater than the brokenstick model, according to the following mathematical expression:

$$
D_{j k}=\left[\sum_{i=1}^{n}\left(X_{i j}-X_{i k}\right)^{2}\right]^{2}
$$

where $\mathrm{D}_{j k}$ represents the Euclidean Distance between species $j$ and $k, n$ corresponds to the number of axes used to calculate the distance, and $\mathrm{X}_{i j}$ and $\mathrm{X}_{i k}$ are the values of the scores of both species on the $i$ axes of the PCA (Gotelli \& Ellison 2004).

Based on the Euclidean Distance calculation between the pairs of species, it was determined, for each mesohabitat, the mean NearestNeighbor Distance (NND), the Standard Deviation of Nearest-Neighbor Distance (SDNND) and the mean Distance to the assemblage Centroid (DC) (Winemiller 1991). The nearest neighbor of a species is the one with whom it has the lowest Euclidean Distance, and the average distance between all the closest neighbors represents the degree of packaging of the species in the ecomorphological space occupied by the assemblage. Thus, the lowest values for NND indicate assemblages with greater packaging in the ecomorphological space, so, species tending to be more similar in terms of body shape. The SDNND is a form of measurement used to represent the evenness of the species packaging in the ecomorphological space. Consequently, the lowest values are related to assemblages in which the distances between the nearest-neighbors are more uniform. The DC represents the volume of the ecomorphological space. To obtain this distance, first, the centroid of the ecomorphological space of the assemblage is determined by calculating the average of the species scores. Then, the mean of the Euclidean distances between the species to the centroid is measured. Thus, higher values indicate the occupation of larger spaces, which may be related to the greater diversity of body shapes and ecological niches explored by the assemblage. The null hypothesis that the values of ecomorphological distances are not significantly different between rural and urban mesohabitats was tested using the two-sample Welch T-test.

Because each stream is considered three times in the ANOVAs (three mesohabitats), stream identity was used as a blocking factor (additive factor) in these analyses, to control its effect on model variance, thus ensuring dependence on mesohabitats. The assumptions of normality and homogeneity of variance were evaluated and met for all ANOVAs by the Shapiro-Wilk and Levene's tests, respectively. All analysis were performed in the R program (R Core Team 2019), using the vegan package (Oksanen et al. 2019).

\section{Results}

\section{Environmental condition}

The mean values and standard deviations of the environmental variables used in this study are described in Table S1. The first two axes of the PCA explained $47.05 \%$ of the total variation of the environmental data and obtained eigenvalues greater than those generated by the broken-stick criterion. The first axis explained $27.52 \%$ and was mainly related to sand (correlation: -0.77$)$, depth $(-0.65)$, rock (0.61), canopy cover by riparian vegetation (0.65), and dissolved oxygen (0.73). On the other hand, the second axis represented $19.54 \%$ of the variation and was mainly related to clay $(-0.71)$, width $(0.61)$, and electrical conductivity (0.73). These variables were responsible for separating the collection points mainly by the land-use type, with the most of urban points positioned in the negative portion of the first axis and the positive portion of the second, while most rural points were on the positive side of the first axis and the negative side of the second (Figure 2).

According to ANOVA, carried out on the scores of the first axis of the PCA, there was a significant separation of points for the factors of land-use type $(\mathrm{F}=65.79, \mathrm{P}<0.01)$ and mesohabitat $(\mathrm{F}=22.27, \mathrm{P}<0.01)$. For the second axis, there was a significant difference for all factors, as well as for the interaction between them (land use type*mesohabitat: $\mathrm{F}=5.92, \mathrm{P}=0.01$ ), indicating that the difference between the landuse type depended on the mesohabitat. Tukey's post hoc test showed that, for the first axis, there was a separation between all mesohabitats (Run-Riffle: $\mathrm{P}=0.01$, Pool-Riffle: $\mathrm{P}>0.01$, Pool-Run: $\mathrm{P}=0.01$ ). For the second axis, the Tukey test showed significant separation between the riffles and the pools of rural streams (rural pools - rural riffles: $\mathrm{P}$ $>0.01$ ), but not among the mesohabitats of urban streams.

\section{Fish assemblage}

A total of 2,195 individuals were sampled belonging to 26 species, 10 families, and six orders (Table 2). Siluriformes was the most representative order in terms of richness with 14 species $(53.8 \%)$, followed by Characiformes with 9 species (34.6\%). Perciformes, Cyprinodontiformes, and Gymnotiformes presented only one individual each, representing $11.5 \%$ of the total richness together. Rural streams showed greater species richness than urban streams, with 26 and 9 species, respectively (Table 2). The mantel correlogram revealed that the correlation coefficient values are not associated with the distance classes (Figure S1), indicating that the composition of the fish assemblage is not related to the watercourse distance between the collection points.

\section{Ecomorphological structure}

The first two axes of the PCA, performed on the correlation matrix of ecomorphological indices, explained $66.74 \%$ of the total variation of the data and were the only ones who obtained eigenvalues greater than those generated by the broken-stick criterion (Table 3), being then used to characterize ecomorphological diversification among the species studied (Figures 3 and 4). Axis 1 (46.05\%) ordered the species, mainly by body shape and relative mouth opening height (Figure 3 ). Thus, species positioned at the negative portion of the axis showed laterally compressed bodies and relatively smaller mouths. On the other hand, those with scores on the positive portion have dorsoventrally depressed bodies and relatively bigger mouths. Axis 2 (20.69\%) showed ecomorphological segregation related mainly to the relative width of the mouth, head length, and areas of the dorsal, caudal, pectoral, and pelvic fins (Figure 3). Therefore, species with scores positioned in the negative portion of the gradient tended to have relatively wider mouths, while the relative length of the head and the relative fins area increased towards the positive portion of the axis.

The gradient formed by the two axes of the PCA showed the morphological diversity of the fish species, which presented different trends of occupation in the mesohabitats (Figure 4). In the rural riffles, 


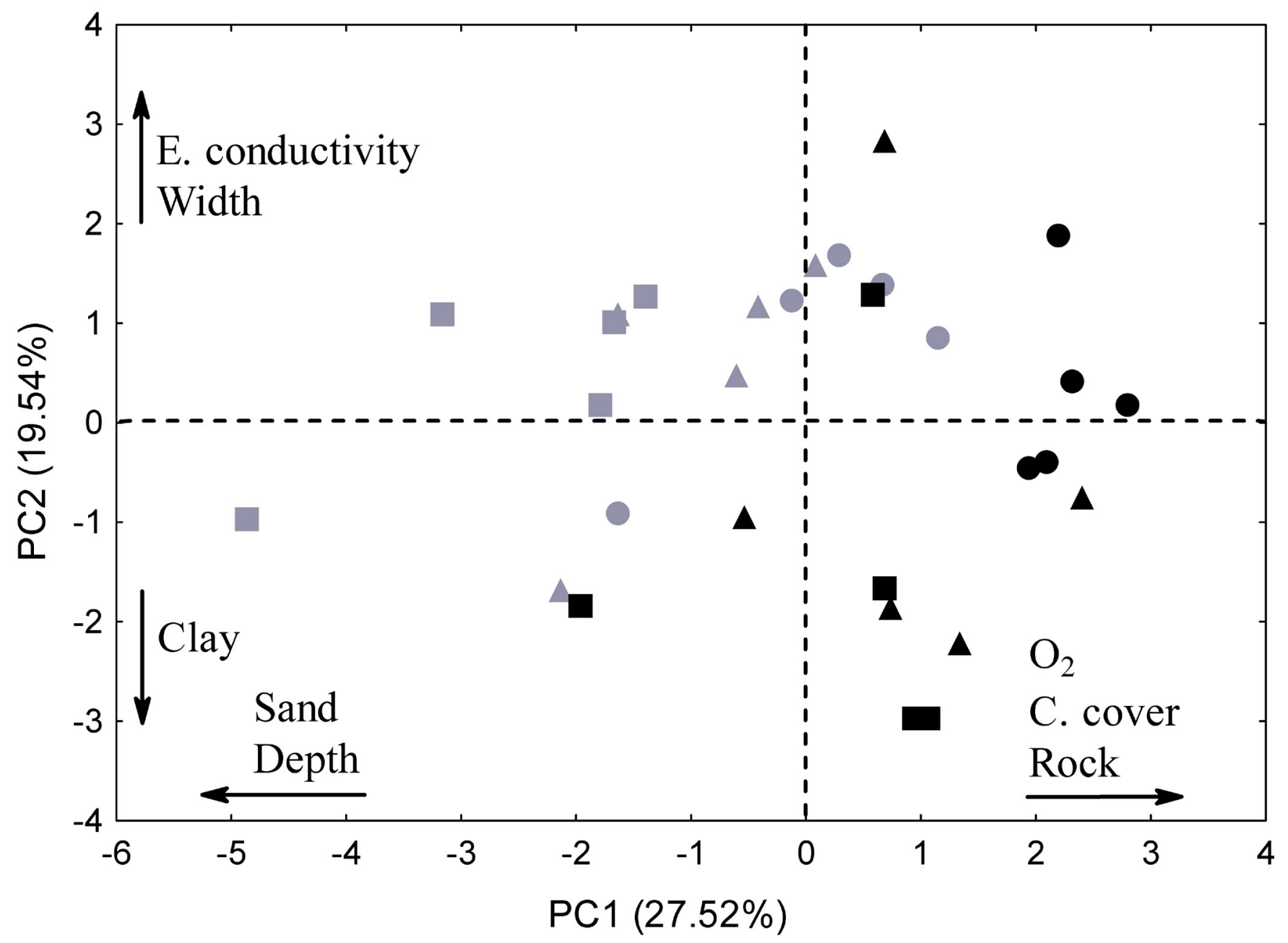

Figure 2. Principal Component Analysis (PCA) based on the environmental variables $(\mathrm{C}$. cover $=$ canopy cover by riparian vegetation and E. conductivity $=$ electrical conductivity) collected in the mesohabitats (riffles $=$ circles, runs $=$ triangles and pools $=$ squares) of five rural streams (black symbols) and five urban streams (gray symbols) of the Pirapó river basin.

there was a tendency of species that were positioned in the positive portion of the first axes and the negative portion of the second axes (Figure 4a); In the rural pools, the tendency was of species that were positioned in the negative portion of the first axes and the positive portion of the second axes (Figure 4c); in rural runs, the trend was less evident, but it was similar to the riffles (Figure 4b). On the other hand, practically the same species occupied the three urban mesohabitats (Figure 4d-f). These different trends influenced ecomorphological distances, increasing the morphological similarity in rural mesohabitats compared to urban ones (Table 4). According to ANOVAs, performed on ecomorphological distances, only the Nearest-Neighbor Distance (NND) showed a significant difference, with significance in the interaction between the factors (land-use type*mesohabitat: $F=4.29$, $\mathrm{P}=0.03$ ). Tukey's post hoc test showed that the significant difference occurred between rural and urban streams, for runs and pools (Table 4).

\section{Discussion}

The results show that the land-use type affects the environmental variables and the fish assemblage in the mesohabitats of streams, with the urban environment presenting less preserved environmental conditions and a decrease in species richness. Regarding ecomorphological distances, mesohabitats from urban streams showed assemblages with less morphological similarity between species (i.e. higher values for NND) without significant changes in the volume of ecomorphological space (DC) and in the evenness of the species packaging in the ecomorphological space (SDNND).

In streams, the hydrological and geomorphological differences among mesohabitats influence the distribution of fish species in the channel (Rezende et al. 2009, Alexandre et al. 2010, Wolff \& Hahn 2017, Huang et al. 2019). This distribution is associated with the morphology of the species, mainly with the body shape (Gaston et al. 2012). Here, this trend has been corroborated for the mesohabitats of rural streams. In riffles, most species have a dorsoventrally depressed body and well-developed caudal peduncle (e.g., Imparfinis mirini, Phenacorhamdia tenebrosa, Hypostomus ancistroides, and Hypostomus strigaticeps); in pools, most species presented a laterally compressed body (e.g., Astyanax lacustris, Astyanax fasciatus, Astyanax paranae and Corydoras aenus); in runs, despite a high relative abundance of I. mirini, A. fasciatus, A. lacustris and C. aenus, there was a greater 
Pessoa, L.A. et al.

Table 2. Taxonomic classification, species code, and abundance of the fish species captured in mesohabitats of rural and urban streams from the Pirapó River basin, Paraná State, Brazil.

\begin{tabular}{|c|c|c|c|c|c|c|c|}
\hline \multirow{2}{*}{ Taxonomic classification } & \multirow{2}{*}{ Code } & \multicolumn{3}{|c|}{ Rural } & \multicolumn{3}{|c|}{ Urban } \\
\hline & & Riffle & Run & Pool & Riffle & Run & Pool \\
\hline \multicolumn{8}{|l|}{ OSTEICHTHYES } \\
\hline \multicolumn{8}{|l|}{ CHARACIFORMES } \\
\hline \multicolumn{8}{|l|}{ Characidae } \\
\hline Astyanax lacustris (Lütken, 1875) & Alac & 1 & 14 & 19 & & & \\
\hline Oligosarcus paranensis Menezes \& Géry, 1983 & & & & 1 & & & \\
\hline Piabina argentea Reinhardt, 1867 & Parg & 11 & 3 & 8 & 11 & 1 & 1 \\
\hline Psalidodon bockmanni (Vari \& Castro, 2007) & Pboc & & & 7 & & & \\
\hline Psalidodon aff. fasciatus (Cuvier, 1819) & Pfas & 1 & 17 & 14 & & 4 & 2 \\
\hline Psalidodon aff. paranae (Eigenmann, 1914) & Ppar & & 6 & 14 & & & \\
\hline \multicolumn{8}{|l|}{ Erythrinidae } \\
\hline \multicolumn{8}{|l|}{ SILURIFORMES } \\
\hline \multicolumn{8}{|l|}{ Callichthyidae } \\
\hline Corydoras aeneus (Gill, 1858) & Caen & 2 & 11 & 12 & & & \\
\hline \multicolumn{8}{|l|}{ Loricariidae } \\
\hline Hisonotus francirochai (Ihering, 1928) & & & 1 & & & & \\
\hline Hypostomus ancistroides (Ihering, 1911) & Hanc & 21 & 2 & 1 & 38 & 12 & 4 \\
\hline Hypostomus hermanni (Ihering, 1905) & Hher & 10 & 2 & 1 & & & \\
\hline Hypostomus cf. nigromaculatus (Schubart, 1964) & Hnig & & 3 & 2 & 83 & 22 & 35 \\
\hline Hypostomus cf. strigaticeps (Regan, 1908) & Hstr & 14 & 4 & & 2 & 2 & \\
\hline Rineloricaria latirostris (Boulenger, 1900) & & 1 & 1 & & & & \\
\hline Phenacorhamdia tenebrosa (Schubart, 1964) & Pten & 24 & 3 & & & & \\
\hline Rhamdia quelen (Quoy \& Gaimard, 1824) & Rque & 9 & 7 & 5 & 25 & 21 & 16 \\
\hline \multicolumn{8}{|l|}{ CICHLIFORMES } \\
\hline \multicolumn{8}{|l|}{ Cichliformes } \\
\hline Geophagus iporangensis Haseman, 1911 & Gipo & & 1 & 10 & & & \\
\hline \multicolumn{8}{|l|}{ CYPRINODONTIFORMES } \\
\hline \multicolumn{8}{|l|}{ Poeciliidae } \\
\hline Poecilia reticulata Peters, 1859 & Pret & 1 & & 2 & 338 & 755 & 369 \\
\hline \multicolumn{8}{|l|}{ GYMNOTIFORMES } \\
\hline \multicolumn{8}{|l|}{ Gymnotidae } \\
\hline Gymnotus inaequilabiatus (Valenciennes, 1839) & Gina & 3 & & & & & \\
\hline
\end{tabular}

richness of species with dorsoventrally depressed bodies (Table 1). This difference in the body shape of most species between riffles, runs, and pools resulted in lower NND values compared to urban ones, i.e. greater morphological similarity in the assemblage of each mesohabitat.

The high current velocity presented in riffles and runs favors species with a dorsoventrally depressed body (Oliveira et al. 2010, Gaston et al. 2012,
Bower \& Piller 2015, Bower \& Winemiller 2019) because this body shape decreases the high energy cost associated with maintaining the position in the water column in fast waters, due to the hydraulic drag exercised over a large body surface area (Webb 1984, 1988). Also, the well-developed caudal peduncle and larger areas of the pectoral fins allow the body to stabilize on the rocky substrate, as well as movement over short distances 
Table 3. Eigenvectors, eigenvalues of the axes, eigenvalue predicted by the broken-stick model, and the percentage of explanation of the first two axes of the PCA based on the 21 ecomorphological indices. The main variables responsible for explaining the species ordering pattern are highlighted.

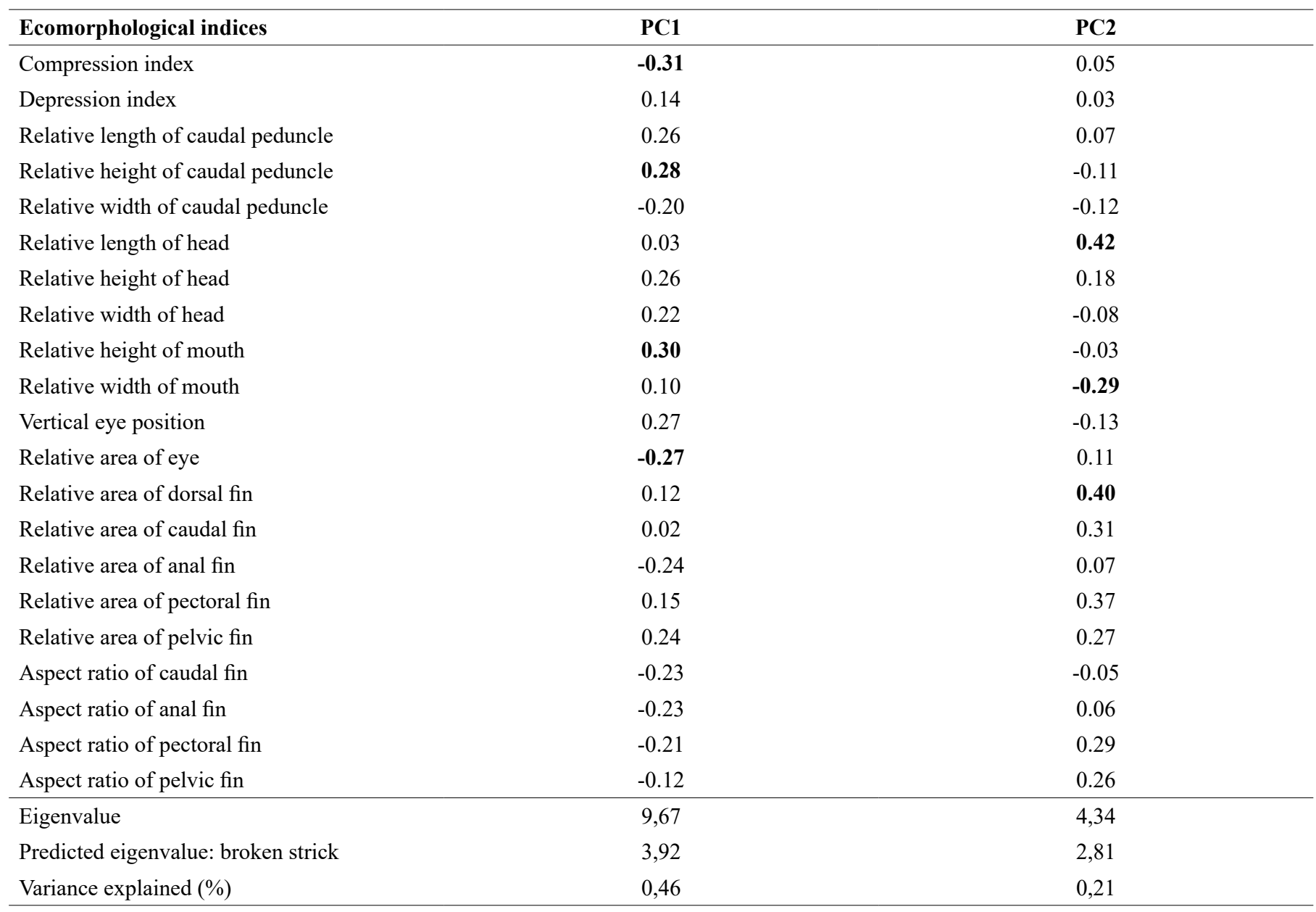

in environments with high current velocity (Oliveira et al. 2010). In contrast, laterally compressed bodies are associated with species that inhabit deeper environments and with lower current velocity (Oliveira et al. 2010, Gaston et al. 2012, Bower \& Winemiller 2019), because this body shape provides greater maneuverability for species (Werner 1977, Gerstner 1999), allowing efficient exploration of more structured lentic environments. The absence of a significant difference in the NND between rural and urban riffles may indicate that this mesohabitat presents greater environmental pressures on the fish assemblage than the others, selecting the morphologically similar species regardless of land-use types. According to Bower \& Winemiller (2019), the high velocity of the water in the riffles function as universal environmental filters for fish species, producing similar assemblage trait in this mesohabitat.

Contrary to the rural environment, and according to what we expected, mesohabitats in urban streams showed a significant decrease in the morphological similarity of the fish assemblage. In our view, this result was due to two factors. First, there was a loss of morphologically similar species in urban mesohabitats, in such a way that only the most distinct species remained. The environmental changes found in urban streams, such as the decrease in canopy cover by riparian vegetation and dissolved oxygen, and the increase in electrical conductivity and bed silting, are characteristic of urban streams worldwide and have been associated with the loss of endemic species and dominance by exotic ones (Walters et al. 2003). Our results show a significant decrease in endemic species and the dominance of $P$. reticulata in all mesohabitats, which is a species that was introduced in many neotropical streams and became dominant in degraded environments (Araujo et al. 2003, Vieira $\&$ Shibatta 2007, Cunico et al. 2012). According to Inward et al. (2011), assemblages exposed to environmental conditions intensely altered by anthropogenic activities tend to have species progressively removed from the ecomorphological space, until only those more distinct from each other remain. This decrease in functional redundancy is one of the main consequences of the simplification of ecosystems by human activities, leading to significant losses in the resilience of assemblages in the face of new disturbances because when only the most distinctly functional species remain, the disappearance of any one of them leads to definitive loss of a function exercised by the assemblage (Laliberté et al. 2010, Bruno et al. 2016).

Second, the species that resisted environmental changes and remained in urban streams showed no difference in composition among mesohabitats. Thus, few species dominated the three urban mesohabitats, being they Poecilia reticulata, Hypostomus nigromaculatus, $H$. ancistroides and Rhandia quelen (Table 2). The homogenization of species among urban mesohabitats resulted in a significant decrease in morphological similarity (i.e., increase in NND) and similar values of the volume of ecomorphological space compared to rural mesohabitats. 
Pessoa, L.A. et al.

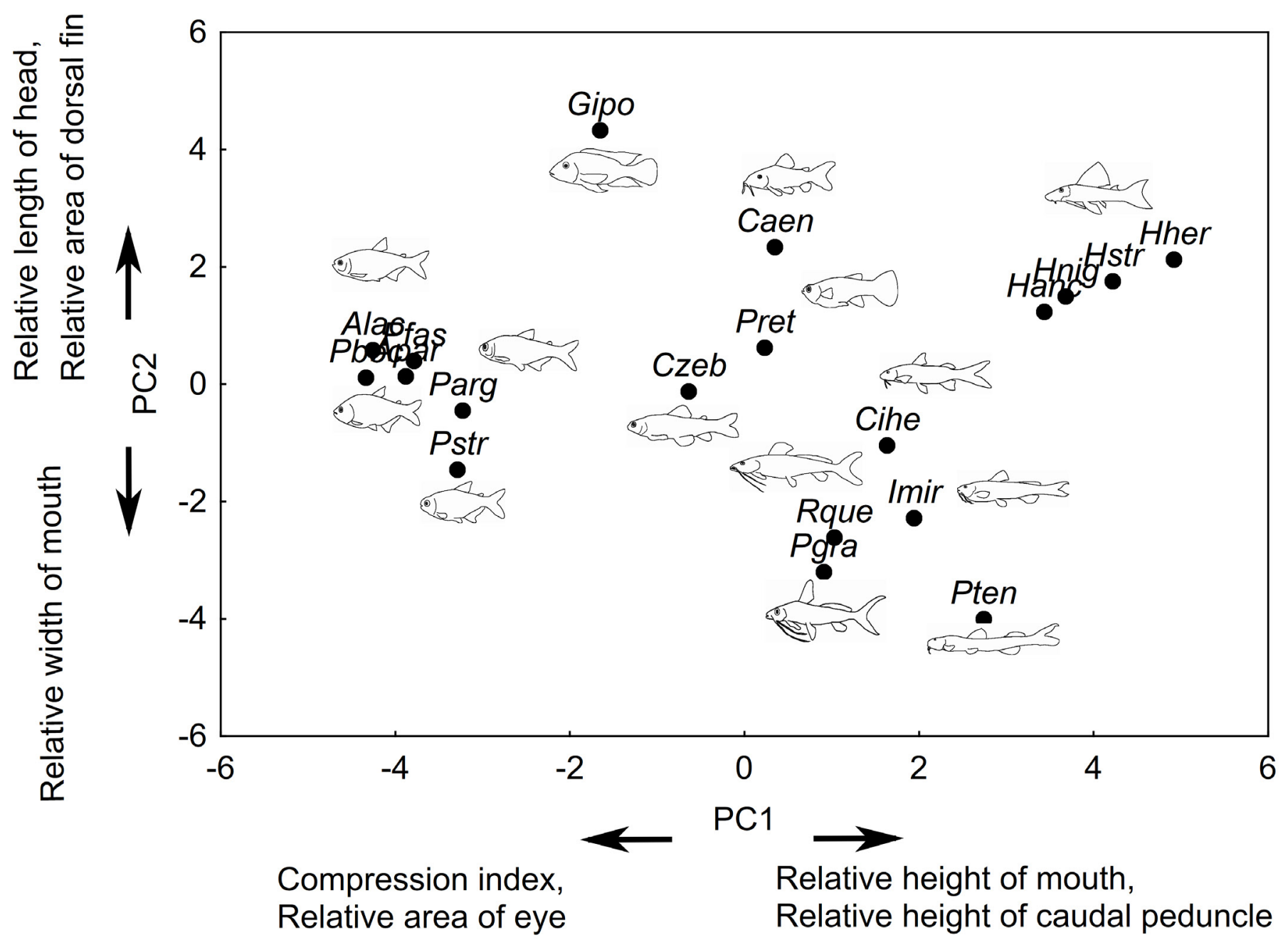

Figure 3. Principal Component Analysis (PCA) based on 21 ecomorphological indices calculated for 19 species. The main variables responsible for explaining the ordering pattern are highlighted in each axis. The species codes are described in Table 2. One species of each genus was designed to improve the visualization of the species' body shape in the ecomorphological space.

This low species turnover among mesohabitats was shown by Teresa \& Casatti (2012) in deforested streams and, as in this study, was the cause of the increase in the functional diversity of the fish assemblage. Here, the homogenization of species may have been caused by changes in environmental variables in urban streams. Although urban mesohabitats present hydrological and geomorphological differences as in rural areas, there was a large proportion of sand in the substrate. As mentioned earlier, the sand can bury the rocky substrate, homogenizing the stream (Walters et al., 2003). However, the silting of the channel was not of great importance in the restructuring of the fish assemblage, since all urban streams presented homogeneous assemblages among the mesohabitats, not just those silted up. The cause of species homogenization among mesohabitats was the presence of civil construction waste (such as bricks and tiles), as we observed, during the collections, these artificial substrates served as hiding places for species of the genus Hypostomus (H. ancistroides and H. nigromaculatus) in the pools.

In summary, we can conclude that the urban environment leads to the loss of morphologically similar fish species in the mesohabitats, with only a few functionally distinct species remaining. Although no function played by the fish assemblage has disappeared in urban mesohabitats, the loss of morphological similarity may have future consequences for these streams. As mentioned earlier, this response of species to environmental changes has led to the loss of the assemblage's resilience in the face of future disturbances. Therefore, management projects must be carried out in such ecosystems with the aim of recovering lost species, and, thus, restore the resilience of the fish assemblage.

\section{Supplementary Material}

The following online material is available for this article:

Figure S1 - Mantel correlation with the fish assemblage composition and hydrological distance matrices between the collection points. Six distance classes were selected, which presented $p$ values $>0.05$, indicating that the fish assemblage composition is not spatially structured.

Table S1 - Mean values and standard deviations of the environmental variables measured in the mesohabitats (Me: Ri, riffles; $\mathrm{Ru}$, runs; Po, pools) of streams (Que, Queçaba; Rom, Romeira; Atl, Atlântico; Ros, Roseira; Lom, Lombo; Man, Mandacaru; Mio, Miosótis; Gua, Guaiapó; Mar, Maringá; Mor, Morangueira) in the Pirapó River hydrographic basin. Abbreviations of environmental variables: O2, Dissolved oxygen; 

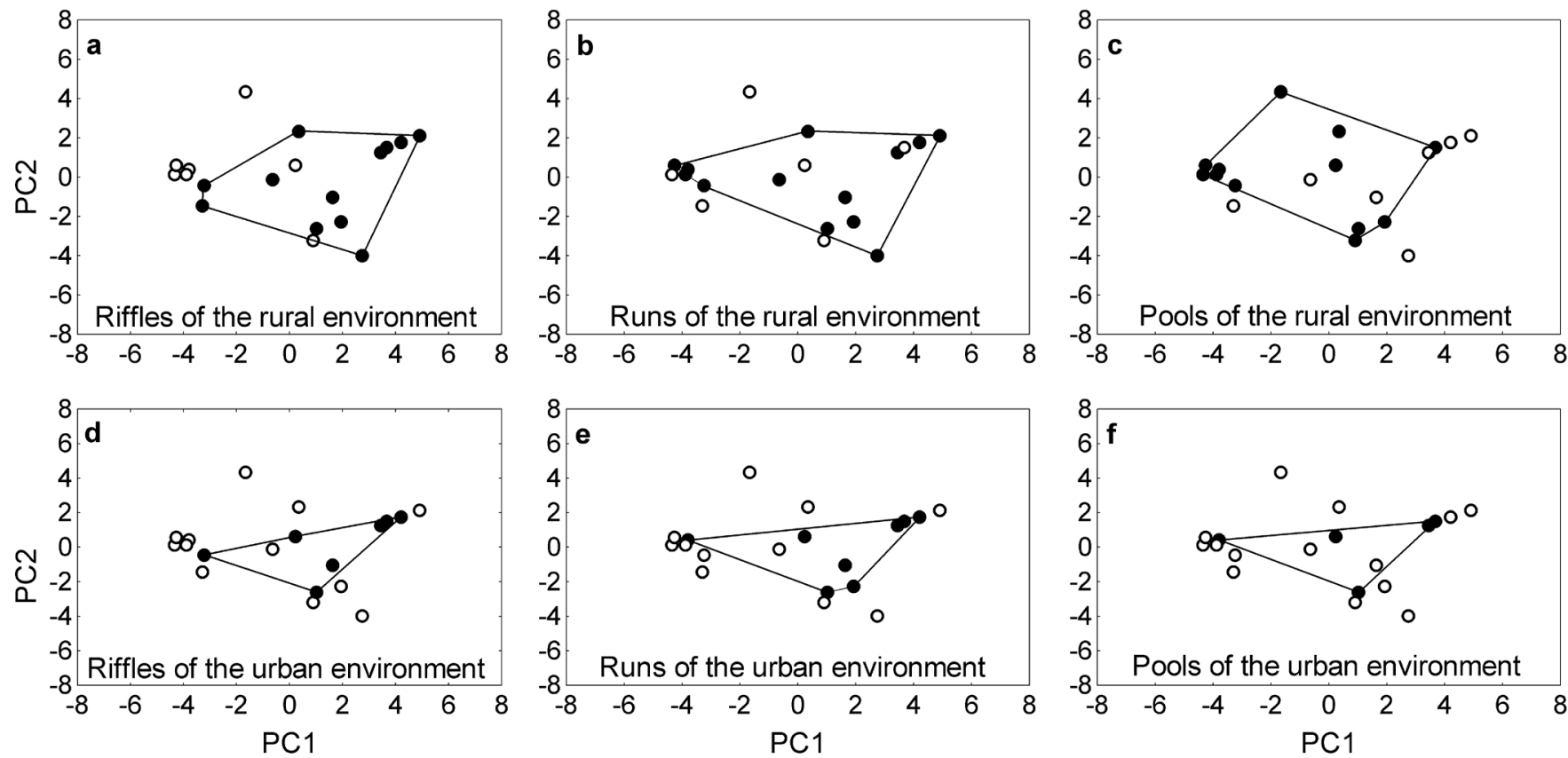

Figure 4. Plots of the first two axes of the Principal Component Analysis based on the 21 ecomorphological indices, showing the species occupation in the ecomorphological space of the mesohabitats of rural (a-c) and urban (d-f) environments. The species collected in each mesohabitat are highlighted (filled symbols) and delimited.

Table 4. Ecomorphological distance values (NND = Nearest-Neighbor Distance, SDNND = Standard Deviation of the Nearest-Neighbor Distance and $\mathbf{D C}=$ Distance to the assemblage Centroid $)$ and Welch's T-test $(\mathrm{T}$ and $\mathrm{P})$ for each mesohabitat $(\mathbf{R i}=$ riffles, $\mathbf{R u}=$ runs, and $\mathbf{P o}=$ pools $)$ of urban and rural streams. For some mesohabitats (X) it was not possible to calculate ecomorphological distances, due to the species richness being less than three.

\begin{tabular}{|c|c|c|c|c|c|c|c|c|c|}
\hline $\begin{array}{l}\text { Streams } \\
\text { Rural }\end{array}$ & \multicolumn{3}{|c|}{ NND } & \multicolumn{3}{|c|}{ SDNND } & \multicolumn{3}{|c|}{ DC } \\
\hline Romeira & 1.60 & 1.35 & 1.25 & 0.82 & 1.40 & 1.61 & 1.69 & 3.43 & 3.20 \\
\hline Roseira & 1.92 & 1.25 & 1.19 & 1.64 & 1.68 & 1.77 & 1.88 & 1.44 & 1.61 \\
\hline Lombo & 1.27 & 1.56 & $\mathrm{X}$ & 0.39 & 1.04 & $\mathrm{X}$ & 2.23 & 2.99 & $\mathrm{X}$ \\
\hline Mandacaru & 3.41 & 3.41 & 3.56 & 0.13 & 0.13 & 0.33 & 2.26 & 2.26 & 2.79 \\
\hline Miosótis & 2.20 & 2.11 & 3.41 & 0.74 & 1.29 & 0.13 & 1.87 & 2.44 & 2.26 \\
\hline Guaiapó & 2.29 & 3.56 & $\mathrm{X}$ & 0.92 & 0.40 & $\mathrm{X}$ & 2.12 & 2.49 & $\mathrm{X}$ \\
\hline Maringá & 1.25 & 1.99 & 1.82 & 0.84 & 1.72 & 1.69 & 1.98 & 2.86 & 2.17 \\
\hline Morangueira & 1.58 & 3.28 & 3.28 & 1.57 & 0.04 & 0.04 & 2.11 & 2.13 & 2.13 \\
\hline
\end{tabular}

Cond, Electric conductivity; Wid, width; Dep, depth; Vel, current velocity; Can, canopy cover by riparian vegetation; Floo, flooded vegetation; San, sand; Civ, civil construction waste; Cla, clay; Roc, rock.

\section{Acknowledgments}

We would like to thank the Graduate Course in Ecology of Inland Aquatic Ecosystems and Nupélia/UEM (Núcleo de Pesquisas em Limnologia, Ictiologia e Aquicultura) for providing us with the logistical support to collect and analyze the materials. We would also like to thank the biologists João Dirço Latini, Wladimir Domingues,
Robson Senna, Rubian Hellen, as well as the electrofishing Nupélia staff (Tato, Tuti, Chiquinho, Valdecir, and Gazo) for helping in field work. Finally, we would like to thank Mário Sérgio Dainez for helping us to develop some of the graphics and two anonymous reviewers for their helpful comments. Funding was provided by CAPES (Coordenação de Aperfeiçoamento de Pessoal de Nível Superior).

\section{Author Contributions}

Leonardo Antunes Pessoa: Substantial contribution in the concept and design of the study; Contribution to data collection; Contribution to data analysis and interpretation; Contribution to manuscript preparation. 
Matheus Tenório Baumgartner: Contribution to data analysis and interpretation; Contribution to manuscript preparation; Contribution to critical revision, adding intelectual content.

Marcelo Percilio Santana Junior: Contribution to data analysis and interpretation; Contribution to manuscript preparation.

João Paulo Alves Pagotto: Substantial contribution in the concept and design of the study; Contribution to critical revision, adding intelectual content.

Luiz Gustavo Antunes Pessoa: Contribution to data analysis and interpretation; Contribution to manuscript preparation.

Erivelto Goulart: Substantial contribution in the concept and design of the study; Contribution to critical revision, adding intelectual content.

\section{Conflicts of Interest}

The authors declare that they have no conflict of interest related to the publication of this manuscript.

\section{Ethics}

The collects were made under the license of the Instituto Chico Mendes de Conservação da Biodiversidade (ICMBIO) n n. 25560-1.

\section{References}

ALEXANDRE, C.V., ESTEVES, K.E. \& DE MOURAE MELLO, M.A.M. 2010. Analysis of fish communities along a rural-urban gradient in a neotropical stream (Piracicaba River Basin, São Paulo, Brazil). Hydrobiologia 641(1):97-114.

ALLAN, J.D. 2004. Landscapes and Riverscapes: The Influence of Land Use on Stream Ecosystems. Annu. Rev. Ecol. Evol. Syst. 35(1):257-284.

ARAUJO, F.G., FICHBERG, I., PINTO, B.C.T. \& PEIXOTO, M.G. 2003. A Preliminary Index of Biotic Integrity for Monitoring the Condition of the Rio Paraiba do Sul, Southeast Brazil. Environ. Manage. 32(4):516-526.

BARBOSA, H. de O., BORGES, P.P., DALA-CORTE, R.B., MARTINS, P.T. de A. \& TERESA, F.B. 2019. Relative importance of local and landscape variables on fish assemblages in streams of Brazilian savanna. Fish. Manag. Ecol. 26(2):119-130.

BOOTH, D.B., KARR, J.R., SCHAUMAN, S., KONRAD, C.P., MORLEY, S.A., LARSON, M.G. \& BURGES, S.J. 2004. Reviving urban streams: land use, hydrology, biology, and human behavior. J. Am. Water Resour. Assoc. 40(5):1351-1364.

BOWER, L.M. \& PILLER, K.R. 2015. Shaping up: a geometric morphometric approach to assemblage ecomorphology. J. Fish Biol. 87(3):691-714.

BOWER, L.M. \& WINEMILLER, K.O. 2019. Fish assemblage convergence along stream environmental gradients: an intercontinental analysis. Ecography (Cop.). 42(10):1691-1702.

BROWN, L.R., GREGORY, M.B. \& MAY, J.T. 2009. Relation of urbanization to stream fish assemblages and species traits in nine metropolitan areas of the United States. Urban Ecosyst. 12(4):391-416.

BRUNO, D., GUTIÉRREZ-CÁNOVAS, C., SÁNCHEZ-FERNÁNDEZ, D., VELASCO, J. \& NILSSON, C. 2016. Impacts of environmental filters on functional redundancy in riparian vegetation J.-T. Li, ed. J. Appl. Ecol. 53(3):846-855.

CASATTI, L. \& CASTRO, R.M.C. 2006. Testing the ecomorphological hypothesis in a headwater riffles fish assemblage of the rio São Francisco, southeastern Brazil. Neotrop. Ichthyol. 4(2):203-214.

CASATTI, L., TERESA, F.B., ZENI, J. de O., RIBEIRO, M.D., BREJÃO, G.L. \& CENEVIVA-BASTOS, M. 2015. More of the Same: High Functional Redundancy in Stream Fish Assemblages from Tropical Agroecosystems. Environ. Manage. 55(6):1300-1314.
CUNICO, A.M., AGOSTINHO, A.A. \& LATINI, J.D. 2006. Influência da urbanização sobre as assembléias de peixes em três córregos de Maringá, Paraná. Rev. Bras. Zool. 23(4):1101-1110.

CUNiCO, A.M., ALLAN, J.D. \& AGOSTINHO, A.A. 2011. Functional convergence of fish assemblages in urban streams of Brazil and the United States. Ecol. Indic. 11(5):1354-1359.

CUNICO, A.M., FERREIRA, E.A., AGOSTINHO, A.A., BEAUMORD, A.C. \& FERNANDES, R. 2012. The effects of local and regional environmental factors on the structure of fish assemblages in the Pirapó Basin, Southern Brazil. Landsc. Urban Plan. 105(3):336-344.

CRUZ, L. C., \& POMPEU, P. S. 2020. Drivers of fish assemblage structures in a Neotropical urban watershed. Urban Ecosyst. 23: 819-829.

FOLEY, J.A., DEFRIES, R., ASNER, G.P., BARFORD, C., BONAN, G., CARPENTER, S.R., CHAPIN, F.S., COE, M.T., DAILY, G.C., GIBBS, H.K., HELKOWSKI, J.H., HOLLOWAY, T., HOWARD, E.A., KUCHARIK, C.J., MONFREDA, C., PATZ, J.A., PRENTICE, I.C., RAMANKUTTY, N. \& SNYDER, P.K. 2005. Global consequences of land use. Science 309(5734):570-4.

GASTON, K.A., EFT, J.A. \& LAUER, T.E. 2012. Morphology and its Effect on Habitat Selection of Stream Fishes. Proc. Indiana Acad. Sci. 121(1):71-78.

GERSTNER, C.L. 1999. Maneuverability of four species of coral-reef fish that differ in body and pectoral-fin morphology. Can. J. Zool. 77(7):1102-1110.

GOTELLI, N.J. \& ELLISON, A.M. 2004. A primer of ecological statistics. 1 ed. Publishers Sunderland, Massachusetts.

GRATWICKE, B., PETROVIC, C. \& SPEIGHT, M.R. 2006. Fish distribution and ontogenetic habitat preferences in non-estuarine lagoons and adjacent reefs. Environ. Biol. Fishes 76(2-4):191-210.

HANCOCK, P.J. 2002. Human Impacts on the Stream-Groundwater Exchange Zone. Environ. Manage. 29(6):763-781.

HASENMUELLER, E.A., CRISS, R.E., WINSTON, W.E. \& SHAUGHNESSY, A.R. 2017. Stream hydrology and geochemistry along a rural to urban land use gradient. Appl. Geochemistry 83136-149.

HUANG, J., HUANG, L., WU, Z., MO, Y., ZOU, Q., WU, N., \& CHEN, Z. 2019. Correlation of Fish Assemblages with Habitat and Environmental Variables in a Headwater Stream Section of Lijiang River, China. Sustainability 11: 1135.

IAT, Instituto Água e Terra. http://www.iat.pr.gov.br/Pagina/Mapas-e-DadosEspaciais (last access in 22/feb/2021)

INWARD, D.J.G., DAVIES, R.G., PERGANDE, C., DENHAM, A.J. \& VOGLER, A.P. 2011. Local and regional ecological morphology of dung beetle assemblages across four biogeographic regions. J. Biogeogr. 38(9):1668-1682.

KANO, Y., MIYAZAKI, Y., TOMIYAMA, Y., MITSUYUKI, C., NISHIDA, S. \& RASHID, Z.A. 2013. Linking Mesohabitat Selection and Ecological Traits of a Fish Assemblage in a Small Tropical Stream (Tinggi River, Pahang Basin) of the Malay Peninsula. Zoolog. Sci. 30(3):178.

KERN, E.M.A. \& LANGERHANS, R.B. 2018. Urbanization drives contemporary evolution in stream fish. Glob. Chang. Biol. 24(8):3791-3803.

LALIBERTÉ,E., WELLS, J.A., DECLERCK, F., METCALFE, D.J., CATTERALL, C.P., QUEIROZ, C., AUBIN, I., BONSER, S.P., DING, Y., FRATERRIGO, J.M., MCNAMARA, S., MORGAN, J.W., MERLOS, D.S., VESK, P.A. \& MAYFIELD, M.M. 2010. Land-use intensification reduces functional redundancy and response diversity in plant communities. Ecol. Lett. 13(1):76-86.

LAYMAN, C.A., LANGERHANS, R.B. \& WINEMILLER, K.O. 2005. Body size, not other morphological traits, characterizes cascading effects in fish assemblage composition following commercial netting. Can. J. Fish. Aquat. Sci. 62(12):2802-2810.

LEAL, C.G., JUNQUEIRA, N.T. \& POMPEU, P.S. 2011. Morphology and habitat use by fishes of the Rio das Velhas basin in southeastern Brazil. Environ. Biol. Fishes 90(2):143-157.

LEITÃO, R.P., SÁNCHEZ-BOTERO, J.I., KASPER, D., TRIVÉRIOCARDOSO, V., ARAÚJO, C.M., ZUANON, J. \& CARAMASCHI, É.P. 2015. Microhabitat segregation and fine ecomorphological dissimilarity between two closely phylogenetically related grazer fishes in an Atlantic Forest stream, Brazil. Environ. Biol. Fishes 98(9):2009-2019.

MAACK, R. 2002. Geografia física do estado do Paraná. 3 ed. Imprensa Oficial, Curitiba. 
MONTAÑA, C.G. \& WINEMILLER, K.O. 2010. Local-scale habitat influences morphological diversity of species assemblages of cichlid fishes in a tropical floodplain river. Ecol. Freshw. Fish 19(2):216-227.

MONTAÑA, C.G., WINEMILLER, K.O. \& SUTTON, A. 2014. Intercontinental comparison of fish ecomorphology: null model tests of community assembly at the patch scale in rivers. Ecol. Monogr. 84(1):91-107.

MORENO, C.E., ARITA, H.T. \& SOLIS, L. 2006. Morphological assembly mechanisms in Neotropical bat assemblages and ensembles within a landscape. Oecologia 149(1):133-140.

NOVAKOWSKI, G.C., FUGI, R. \& HAHN, N.S. 2004. Diet and dental development of three species of Roeboides (Characiformes: Characidae). Neotrop. Ichthyol. 2(3):157-162.

OKSANEN, J., BLANCHET, F.G., FRIENDLY, M., KINDT, R., LEGENDRE, P., MCGLINN, D., MINCHIN, P.R., O'HARA, R.B., SIMPSON, G.L., SOLYMOS, P., STEVENS, M.H.H., SZOECS, E. \& WAGNER, H. 2019. vegan: Community Ecology Package.

OLIVEIRA, E.F., GOULART, E., BREDA, L., MINTE-VERA, C.V., PAIVA, L.R. de S. \& VISMARA, M.R. 2010. Ecomorphological patterns of the fish assemblage in a tropical floodplain: effects of trophic, spatial and phylogenetic structures. Neotrop. Ichthyol. 8(3):569-586.

OTA, R.R., DEPRÁ, G. de C., GRAÇA, W.J. da \& PAVANELLI, C.S. 2018. Peixes da planície de inundação do alto rio Paraná e áreas adjacentes: revised, annotated and updated. Neotrop. Ichthyol. 16(2):1-111.

PAGOTTO, J., GOULART, E., OLIVEIRA, E. \& YAMAMURA, C. 2011. Trophic ecomorphology of Siluriformes (Pisces, Osteichthyes) from a tropical stream. Brazilian J. Biol. 71(2):469-479.

PASSOS, M.M. 2007. A raia divisória: eco-história da raia divisória. 2 ed. Eduem, Maringá

PEASE, A.A., GONZÁLEZ-DÍAS, A.A., RODILES-HERNÁNDEZ, R. \& WINEMILLER, K.O. 2012. Functional diversity and trait-environment relationships of stream fish assemblages in a large tropical catchment. Freshw. Biol. 57(5):1060-1075.

PERES-NETO, P.R. 1999. Alguns métodos e estudos em ecomorfologia de peixes de riachos. In Ecologia de peixes de riachos (E. P. Caramashi, R Mazzoni, \& P. R. Peres-Neto, eds) PPGE-UFRJ, Rio de Janeiro, p.209-236.

PERKIN, J.S., MURPHY, S.P., MURRAY, C.M., GIBBS, W.K. \& GEBHARD, A.E 2019. If you build it, they will go: A case study of stream fish diversity loss in an urbanizing riverscape. Aquat. Conserv. Mar. Freshw. Ecosyst. 29(4):623-638.

QGIS DEVELOPMENT TEAM. 2018. QGIS Geographic Information System. Open Source Geospatial Foundation Project.

R CORE TEAM. 2020. R: A Language and Environment for Statistical Computing. Vienna: R Foundation for Statistical Computing. https://www.Rproject.org/RABENI, C.F. \& SMALE, M.A. 1995. Effects of siltation on stream fishes and the potential mitigating role of the buffering riparian zone. Hydrobiologia 303(1-3):211-219.

RASBAND WS.1997-2012. ImageJ, U.S. National Institutes of Health, Bethesda, Maryland, USA. imagej.nih.gov/ij/RINCÓN, P.A. 1999. Uso do Micro-hábitat em Peixes de Riachos: Métodos e Perspectivas. In Ecologia de peixes de riachos Série Oecologia Brasiliensis, Rio de Janeiro, p.23-90.

RUSSO, T., COSTA, C. \& CATAUDELLA, S. 2007. Correspondence between shape and feeding habit changes throughout ontogeny of gilthead sea bream Sparus aurata L., 1758. J. Fish Biol. 71(3):629-656.

SALA, O.E., CHAPIN, F.S., ARMESTO, J.J., BERLOW, E., BLOOMFIELD, J., DIRZO, R., HUBER-SANWALD, E., HUENNEKE, L.F., JACKSON, R.B. KINZIG,A., LEEMANS, R., LODGE, D.M., MOONEY,H.A., OESTERHELD, M., POFF, N.L., SYKES, M.T., WALKER, B.H., WALKER, M. \& WALL, D.H. 2000. Global biodiversity scenarios for the year 2100. Science 287(5459):1770-4.
TERESA, F.B. \& CASATTI, L. 2012. Influence of forest cover and mesohabitat types on functional and taxonomic diversity of fish communities in Neotropical lowland streams. Ecol. Freshw. Fish 21(3):433-442.

TÓTH, R., CZEGLÉDI, I., KERN, B. \& ERÖS, T. 2019. Land use effects in riverscapes: Diversity and environmental drivers of stream fish communities in protected, agricultural and urban landscapes. Ecol. Indic. 101(August 2018):742-748.

TOUSSAINT, A., CHARPIN, N., BROSSE, S. \& VILLÉGER, S. 2016. Global functional diversity of freshwater fish is concentrated in the Neotropics while functional vulnerability is widespread. Sci. Rep. 6(1):22125.

VIEIRA, D.B. \& SHIBATTA, O.A. 2007. Peixes como indicadores da qualidade ambiental do ribeirão Esperança, município de Londrina, Paraná, Brasil. Biota Neotrop. 7(1):57-65.

VILLÉGER, S., MIRANDA, J.R., HERNÁNDEZ, D.F. \& MOUILLOT, D. 2010. Contrasting changes in taxonomic vs. functional diversity of tropical fish communities after habitat degradation. Ecol. Appl. 20(6):1512-1522.

WALSH, C.J., ROY,A.H., FEMINELLA, J.W., COTTINGHAM, P.D., GROFFMAN, P.M. \& MORGAN, R.P. 2005. The urban stream syndrome: current knowledge and the search for a cure. J. North Am. Benthol. Soc. 24(3):706-723.

WALTERS, D.M., LEIGH, D.S. \& BEARDEN, A.B. 2003. Urbanization, sedimentation, and the homogenization of fish assemblages in the Etowah River Basin, USA. Hydrobiologia 494(1-3):5-10.

WANG, L., LYONS, J., KANEHL, P. \& BANNERMAN, R. 2001. Impacts of Urbanization on Stream Habitat and Fish Across Multiple Spatial Scales. Environ. Manage. 28(2):255-266.

WEAVER, L.A. \& GARMAN, G.C. 1994. Urbanization of a Watershed and Historical Changes in a Stream Fish Assemblage. Trans. Am. Fish. Soc. 123(2):162-172.

WEBB, P.W. 1984. Form and function in fish swimming. Scientific American 251(7):72-82.

WEBB, P.W. 1988. Simple Physical Principles and Vertebrate Aquatic Locomotion. American Zoologist 28(2): 709-725.

WERNER, E.E. 1977. Species Packing and Niche Complementarity in Three Sunfishes. Am. Nat. 111(979):553-578.

WIKRAMANAYAKE, E.D. 1990. Ecomorphology and Biogeography of a Tropical Stream Fish Assemblage: Evolution of Assemblage Structure. Ecology 71(5):1756-1764.

WILLIS, S.C., WINEMILLER, K.O. \& LOPEZ-FERNANDEZ, H. 2005. Habitat structural complexity and morphological diversity of fish assemblages in a Neotropical floodplain river. Oecologia 142(2):284-295.

WINEMILLER, K.O. 1991. Ecomorphological Diversification in Lowland Freshwater Fish Assemblages from Five Biotic Regions. Ecol. Monogr. 61(4):343-365.

WOLFF, L. L., \& HAHN, S. N. 2017. Fish habitat associations along a longitudinal gradient in a preserved coastal Atlantic stream, Brazil. Zoologia, 34: 1-13.

WOOD, P.J. \& ARMITAGE, P.D. 1997. Biological Effects of Fine Sediment in the Lotic Environment. Environ. Manage. 21(2):203-217.

ZENI, J. O., PÉREZ-MAYORGA, M. A., ROA-FUENTES, C. A., BREJÃO, G. L., \& CASATTI, L. 2019. How deforestation drives stream habitat changes and the functional structure of fish asse mblages in different tropical regions. Aquat. Conserv. Mar. Freshw. Ecosyst. 29: 1238-1252.

Received: 08/05/2020

Revised: 04/05/2021

Accepted: 16/05/2021

Published online: 18/06/2021 